\title{
CEREBRAL VASCULAR RESPONSES TO KETAMINE AND THIOPENTONE DURING FOETAL ACIDOSIS
}

\author{
Brian G. Pickering, Richard J. Palahniuk, Jacques Coté, John G. Wade and \\ Michael G. PASH
}

\begin{abstract}
Using a chronic sheep preparation, with induced foetal acidosis, the effects of low and high dose thiopentone and ketamine on maternal and foetal cardiovascular dynamics were studied. Ketamine $4 \mathrm{mg} \cdot \mathrm{kg}^{-1}$ and thiopentone $10 \mathrm{mg} \cdot \mathrm{kg}^{-1}$ were both associated with marked reductions in foetal cerebral blood flow and cerebral oxygen delivery. Blood pressure and cerebral blood flow in the acidotic foetus was better preserved, however, following the lower dose of ketamine $2 \mathrm{mg} \cdot \mathrm{kg}^{-1}$ than following thiopentone $6 \mathrm{mg} \cdot \mathrm{kg}^{-1}$.
\end{abstract}

KEY WordS: BraIN, vascular responses, foetal acidosis; ANAESTHESIA, obstetrical, complications, foetal acidosis; ANAESTHETICS, intravenous, ketamine, thiopentone.

PERINATAL ASPHYXIa is a major cause of permanent neurological damage. ${ }^{\prime}$ Investigations in both sheep and humans have demonstrated that the normal foetal response to an acidotic or asphyxial stress is an increase in cerebral blood flow by vasodilation, and loss of autoregulation of cerebral perfusion in response to changes in blood pressure. ${ }^{2,3}$ This results in two potential hazards to the asphyxiated foetus or neonate. First, drugs or factors which promote hypertension may predispose to cerebral haemorrhage and, second, drugs or factors which promote hypotension may predispose to cerebral ischaemia. $^{4}$

Ketamine and thiopentone have both been advocated as induction agents in obstetrical anaesthesia and are currently the most popular drugs for induction of general anaesthesia in both emergency and elective situations. ${ }^{5}$ The present investigation was designed to determine the effects of low and high doses of ketamine and thiopentone on the cardiovascular and cerebro-

Brian G. Pickering, M.D., Lecturer; Richard J. Palahniuk, M.D., Professor; Jacques Cote, M.D., Research Fellow; John G. Wade, M. D., Professor; Michael G. Pash, M.D., Lecturer; Department of Anaesthesia, University of Manitoba, Winnipeg, Manitoba.

Presented in part at the Canadian Anaesthetists' Society Meeting, Edmonton, 1979.

Supported by the Medical Research Council of Canada and the Canadian Heart Foundation.

Reprint requests to: Dr. Richard J. Palahniuk, Department of Anaesthesia, University of Manitoba, AD201, Interne's Residence, 720 McDermot Ave., Winnipeg, Manitoba, R3E 0Z3. vascular systems of foetal sheep made acidotic in utero.

\section{Methods}

The study was approved by our Animal Experimentation Committee as conforming to guidelines for the humane use of animals in research. Fourteen pregnant ewes with single foetuses estimated to be between 130 and 140 days of gestation (term-150 days) were used in the studies. The animals were prepared at least one day before any study in the following fashion. The ewe was anaesthetized with halothane and oxygen, intubated and ventilated to maintain . normal $\mathrm{Paco}_{2}$. A maternal femoral artery and vein were cannulated. The foetus was exposed through a hysterotomy incision, and a foetal axillary artery catheter was passed into the common brachiocephalic trunk. A catheter was also passed into the foetal inferior vena cava through the femoral vein, and a femoral artery catheter was inserted into the abdominal aorta. An inflatable cuff was placed around the umbilical cord. All lines were brought to the skin in the ewe's flank and the incisions were closed. Preparations similar to this have been used successfully in several previous studies from our laboratory. 2.6 .7

The mother and foetus were allowed to recover for 1-2 days before the study. On the morning of study, maternal and foetal blood gases, acid-base balance and blood pressure were measured. If these values were not in the normal range, the preparation was not used. 
TABLE I

Thiopentone - Maternal Data (Mean \pm SE)

\begin{tabular}{|c|c|c|c|c|}
\hline \multirow[b]{3}{*}{$\begin{array}{l}\text { Arterial Blood Pressure (torr) } \\
\mathrm{PaO}_{2} \text { (torr) } \\
\mathrm{PaO}_{2} \text { (torr) } \\
\mathrm{Ph}\end{array}$} & \multirow[b]{2}{*}{ Control } & \multirow[b]{2}{*}{ Acidosis } & \multicolumn{2}{|c|}{ Thiopentone } \\
\hline & & & $6 \mathrm{mg} \cdot \mathrm{kg}^{-1}$ & $10 \mathrm{mg} \cdot \mathrm{kg}^{-1}$ \\
\hline & $\begin{array}{ll}95 & \pm 5 \\
89 & \pm 2 \\
24 & \pm 1 \\
7.46 & \pm 0.03\end{array}$ & $\begin{array}{ll}91 & \pm 4 \\
97 & \pm 3 \\
21 & \pm 2 \\
7.44 & \pm 0.02\end{array}$ & $\begin{array}{ll}94 & \pm 7 \\
80 & \pm 3^{*} \\
25 & \pm 1 \\
7.41 & \pm 0.01\end{array}$ & $\begin{array}{ll}95 & \pm 4 \\
56 & \pm 10^{*} \\
32 & \pm 3^{*} \\
7.37 & \pm 0.02 \dagger\end{array}$ \\
\hline
\end{tabular}

During each study, maternal and foetal blood pressures (BP) and heart rates (HR) were monitored continuously through the femoral artery catheters using Statham P-23 transducers adapted to read on a Hewlett-Packard polygraph. Maternal and foetal arterial $\mathrm{PO}_{2}, \mathrm{PCO}_{2}$ and $\mathrm{pH}$ were measured on a Corning 165 blood gas analyzer and temperature corrected. Base excess (BE) and foetal oxygen saturation $\left(\mathrm{Sao}_{2}\right)$ were calculated using the appropriate nomograms. ${ }^{8}$ Foetal regional cerebral blood flow (rCBF) measurements were made using radioactive microspheres as described previously. ${ }^{9}$

On the day of study, control measurements of $\mathrm{PaO}_{2}, \mathrm{Paco}_{2}, \mathrm{pH}, \mathrm{BP}$ and $\mathrm{HR}$ were made with the awake ewe standing quietly in her cage. The foetus was then made acidotic to a $\mathrm{pH}$ near 7.10 by incremental inflation of the occlusion cuff around the umbilical cord over $1-2$ hours. When the $\mathrm{pH}$ had stabilized near 7.10 for 30 minutes, measurements of rCBF, blood gas and acid-base values, and $B P$ and HR were made (acidosis values). The mother was then given either ketamine or thiopentone intravenously in a low or a high dose. Following the administration of the drug, repeat measurements of all variables were done and the mother was allowed to recover until all vital signs had returned to control values. The second dose of the same agent was then administered and all variables were measured a third time. Oxygen was administered and the ewe breathed spontaneously throughout the study period. Each ewe received only one drug (thiopentone $6 \mathrm{mg} \cdot \mathrm{kg}^{-1}$ and $10 \mathrm{mg} \cdot \mathrm{kg}^{-1}$ or ketamine $2 \mathrm{mg} \cdot \mathrm{kg}^{-1}$ and $4 \mathrm{mg} \cdot \mathrm{kg}^{-1}$ ). Low and high dose administrations were randomized. In all, six ewes received thiopentone and eight received ketamine.

Following completion of the study, vital signs were allowed to retum to control values and the mother and foetus were sacrificed. Autopsy was done to confirm foetal size and catheter place- ment. Samples were obtained from foetal cerebral cortex, cerebellum, brain stem and basal ganglia for radioisotope counting and calculation of rCBF for the three periods (acidosis, low dose induction agent, high dose induction agent). An estimation of cerebral oxygen delivery during each period was calculated as rCBF $x$ $\mathrm{SaO}_{2}$. Data were analyzed using the paired t-test and regression and correlation analysis as indicated. Means and standard errors for the $\mathrm{pH}$ data were obtained by analyzing the $\mathrm{pH}$ values directly. $P<0.05$ was used to determine statistical significance.

\section{REsUlTS}

Maternal responses to the two induction agents are shown in Table I and II. Maternal cardiovascular, acid-base and blood gas variables were well-maintined following either thiopentone $6 \mathrm{mg} \cdot \mathrm{kg}^{-1}$ or ketamine $2 \mathrm{mg} \cdot \mathrm{kg}^{-1}$ but some deterioration was noted after the higher doses of both agents.

Foetal cardiovascular and acid-base responses are shown in Tales III and IV. As might be expected, foetal blood pressure tended to rise with acidosis and return toward or below control values following the administration of drugs. Thiopentone $10 \mathrm{mg} \cdot \mathrm{kg}^{-1}$ produced the most foetal hypotension, a fall to 78 per cent of the blood pressure seen during acidosis alone. Reductions in foetal $\mathrm{pH}$ and $\mathrm{BE}$ were most marked after the higher dose of thiopentone. An unexpected finding was the consistent and marked foetal tachycardia seen after both doses of thiopentone and not seen with ketamine.

The corresponding foetal rCBF values are shown in Tables $\mathrm{V}$ and VI. Both doses of thiopentone were associated with sizeable reductions in flow although these only reached significance with the $10 \mathrm{mg} \cdot \mathrm{kg}^{-1}$ dose. Ketamine $2 \mathrm{mg} \cdot \mathrm{kg}^{-1}$ tended to maintain rCBF values but 
TABLE II

Ketamine - Maternal Data (Mean \pm SE)

\begin{tabular}{|c|c|c|c|c|}
\hline \multirow[b]{3}{*}{$\begin{array}{l}\text { Arterial Blood Pressure (tort) } \\
\mathrm{PaO}_{2} \text { (torr) } \\
\mathrm{PaO}_{2} \text { (torr) } \\
\mathrm{pH}\end{array}$} & \multirow[b]{2}{*}{ Control } & \multirow[b]{2}{*}{ Acidosis } & \multicolumn{2}{|c|}{ Ketamine } \\
\hline & & & $2 \mathrm{mg} \cdot \mathrm{kg}^{-1}$ & $4 \mathrm{mg} \cdot \mathrm{kg}^{-1}$ \\
\hline & $\begin{array}{l}98 \quad \pm 6 \\
87 \quad \pm 3 \\
24 \quad \pm 1 \\
7.56 \pm 0.01\end{array}$ & $\begin{array}{ll}90 & \pm 4 \\
87 & \pm 4 \\
27 & \pm 1 \\
7.53 & \pm 0.02\end{array}$ & $\begin{array}{ll}94 & \pm 7 \\
76 & \pm 3^{*} \\
28 & \pm 1 \\
7.46 & \pm 0.04 \dagger\end{array}$ & $\begin{array}{l}87 \pm 3^{\dagger} \\
73 \quad \pm 4^{*} \\
31 \quad \pm 1 \dagger \\
7.43 \pm 0.03^{*}\end{array}$ \\
\hline
\end{tabular}

TABLE III

Thiopentone - Foetal Data (Mean $\pm \mathrm{SE})$

\begin{tabular}{|c|c|c|c|c|c|}
\hline & & & \multicolumn{3}{|c|}{ Thiopentone } \\
\hline & Control & Acidosis & $6 \mathrm{mg} \cdot \mathrm{kg}^{-1}$ & \multicolumn{2}{|c|}{$10 \mathrm{mg} \cdot \mathrm{kg}^{-1}$} \\
\hline $\begin{array}{l}\text { Arterial Blood Pressure (torr) } \\
\text { Heart Rate } \\
\mathrm{PaO}_{2} \text { (torr) } \\
\mathrm{Paco}_{2} \text { (torr) } \\
\mathrm{pH} \\
\mathrm{BE}(\mathrm{mmol} / 1) \\
\mathrm{SaO}_{2}(\%)\end{array}$ & $\begin{aligned} 58 & \pm 4 \\
160 & \pm 11 \\
16 & \pm 1.4 \\
35 & \pm 1.2 \\
7.35 & \pm 0.02 \\
-4.1 & \pm 0.8 \\
32 & \pm 6.4\end{aligned}$ & $\begin{aligned} 63 & \pm 6 \\
160 & \pm 24 \\
18 & \pm 1.6 \\
46 & \pm 3.1 \dagger \\
17.10 & \pm 0.02 \dagger \\
-15.3 & \pm 0.9 \dagger \\
23 & \pm 4.8 \dagger\end{aligned}$ & $\begin{aligned} 54 & \pm 6 \\
243 & \pm 16^{*} \\
19 & \pm 1.9 \\
46 & \pm 3.1 \dagger \\
7.08 & \pm 0.02 \dagger \\
-15.9 & \pm 1.3 \dagger \\
25 & \pm 5.9\end{aligned}$ & $\begin{array}{r}49 \\
255 \\
18 \\
51 \\
6.99 \\
-20.2 \\
21\end{array}$ & $\begin{array}{l} \pm 6 \ddagger \\
\pm 7 * \\
\pm 2.8 \\
\pm 6.4 \dagger \\
\pm 0.07 \dagger \\
\pm 2.6 \dagger \\
\pm 8.9\end{array}$ \\
\hline
\end{tabular}

* = significant change from control and acidosis values.

$\dagger=$ significant change from control only.

$\ddagger=$ significant change from acjdosis only.

TABLE IV

Ketamine - Foetal Data (Mean \pm SE)

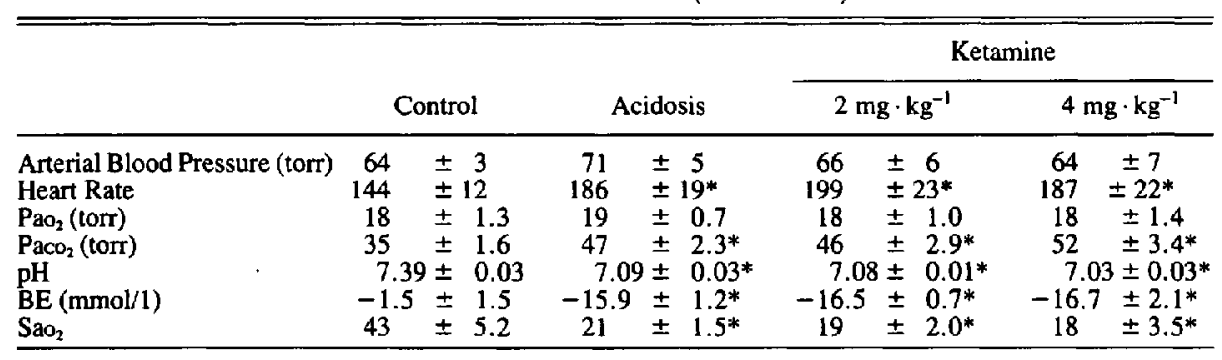

* = significant change from control.

TABLE V

ThIOPENTONe - FoETAL rCBF (MEAN + SE)

\begin{tabular}{|c|c|c|c|c|c|}
\hline & \multirow[b]{3}{*}{$\begin{array}{c}\text { Acidosis } \\
\mathrm{ml} / 100 \mathrm{~g} / \mathrm{min}\end{array}$} & \multicolumn{4}{|c|}{ Thiopentone } \\
\hline & & \multicolumn{2}{|c|}{$6 \mathrm{mg} \cdot \mathrm{kg}^{-1}$} & \multicolumn{2}{|c|}{$10 \mathrm{mg} \cdot \mathrm{kg}^{-1}$} \\
\hline & & $\mathrm{ml} / 100 \mathrm{~g} / \mathrm{min}$ & $\begin{array}{c}\text { \% Change from } \\
\text { Acidosis }\end{array}$ & $\mathrm{ml} / 100 \mathrm{~g} / \mathrm{min}$ & $\begin{array}{c}\text { \% Change from } \\
\text { Acidosis }\end{array}$ \\
\hline $\begin{array}{l}\text { Cerebral Cortex } \\
\text { Cerebellum } \\
\text { Basal Ganglia } \\
\text { Brain Stem }\end{array}$ & $\begin{array}{l}208 \pm 39 \\
325 \pm 56 \\
414 \pm 82 \\
475 \pm 87\end{array}$ & $\begin{array}{l}166 \pm 32 \\
260 \pm 44 \\
296 \pm 70^{*} \\
361 \pm 82\end{array}$ & $\begin{array}{l}-16 \\
-20 \\
-25 \\
-20\end{array}$ & $\begin{array}{l}113 \pm 30^{*} \\
203 \pm 56^{*} \\
233 \pm 67^{*} \\
271 \pm 66^{*}\end{array}$ & $\begin{array}{l}-37 \\
-42 \\
-39 \\
-38\end{array}$ \\
\hline
\end{tabular}

* = Significant change from acidosis values. 
TABLE VI

Ketamine - Foetal rCBF (MeAN + SE)

\begin{tabular}{|c|c|c|c|c|c|}
\hline & \multirow[b]{3}{*}{$\begin{array}{c}\text { Acidosis } \\
\mathrm{ml} / 100 \mathrm{~g} / \mathrm{min}\end{array}$} & \multicolumn{4}{|c|}{ Ketamine } \\
\hline & & \multicolumn{2}{|c|}{$2 \mathrm{mg} \cdot \mathrm{kg}^{-1}$} & \multicolumn{2}{|c|}{$4 \mathrm{mg} \cdot \mathrm{kg}^{-1}$} \\
\hline & & $\mathrm{ml} / 100 \mathrm{~g} / \mathrm{min}$ & $\begin{array}{l}\text { \%Change from } \\
\text { Acidosis }\end{array}$ & $\mathrm{ml} / 100 \mathrm{~g} / \mathrm{min}$ & $\begin{array}{l}\text { \%Change from } \\
\text { Acidosis }\end{array}$ \\
\hline $\begin{array}{l}\text { Cerebral Cortex } \\
\text { Cerebellum } \\
\text { Basal Ganglia } \\
\text { Brain Stem }\end{array}$ & $\begin{array}{l}178 \pm 34 \\
264 \pm 31 \\
347 \pm 69 \\
408 \pm 74\end{array}$ & $\begin{array}{l}166 \pm 33 \\
261 \pm 40 \\
325 \pm 72 \\
356 \pm 66\end{array}$ & $\begin{array}{l}-7 \\
-1 \\
-6 \\
-13\end{array}$ & $\begin{array}{l}121 \pm 31^{*} \\
195 \pm 39^{*} \\
220 \pm 52^{*} \\
251 \pm 60^{*}\end{array}$ & $\begin{array}{l}-32 \\
-26 \\
-37 \\
-38\end{array}$ \\
\hline
\end{tabular}

$*=$ Significant change from acidosis value.

\section{TABLE VII}

Thiopentone \& Ketamine - Foetal Cerebral Oxygen Delivery as Per CENT OF ACIDOSIS VALUeS (MEAN \pm SE)

\begin{tabular}{lccccc}
\hline & \multicolumn{2}{c}{ Thiopentone } & & \multicolumn{2}{c}{ Ketamine } \\
\cline { 2 - 3 } \cline { 5 - 6 } & $6 \mathrm{mg} \cdot \mathrm{kg}^{-1}$ & $10 \mathrm{mg} \cdot \mathrm{kg}^{-1}$ & & $2 \mathrm{mg} \cdot \mathrm{kg}^{-1}$ & $4 \mathrm{mg} \cdot \mathrm{kg}^{-1}$ \\
\hline Cerebral Cortex & $92 \pm 16$ & $51 \pm 18^{*}$ & & $82 \pm 11$ & $56 \pm 13^{*}$ \\
Cerebellum & $89 \pm 17$ & $62 \pm 22$ & & $88 \pm 10$ & $64 \pm 14^{*}$ \\
Basal Ganglia & $84 \pm 9$ & $53 \pm 18^{*}$ & & $85 \pm 12$ & $53 \pm 12^{*}$ \\
Brain Stem & $89 \pm 16$ & $57 \pm 18^{*}$ & & $78 \pm 10^{*}$ & $50 \pm 11^{*}$ \\
\hline
\end{tabular}

* = Significant change from acidosis value.

$4 \mathrm{mg} \cdot \mathrm{kg}^{-1}$ was associated with significant reductions of a magnitude similar to the higher dose of thiopentone.

Estimations of regional cerebral oxygen delivery are presented in Table VII. As might be expected from the $\mathrm{rCBF}$ and $\mathrm{Sao}_{2}$ values, oxygen delivery was markedly reduced by the higher doses of both agents.

\section{Discussion}

Thiopentone and ketamine are the two most commonly used induction agents for obstetrical general anaesthesia. Studies in healthy patients have suggested that low doses of either ketamine or thiopentone are safe for the foetus in utero. ${ }^{10-12}$ Although the studies have not been done with foetal asphyxia, the data from healthy patients have been extrapolated to the high risk situation to suggest their use in this situation is also safe. The present study, albeit in animals, would suggest that ketamine might be preferable in the face of suspected foetal acidosis. Even at the lower dose, thiopentone was associated with a more marked reduction in foetal blood pressure and cerebral blood flow.

An explanation for the response observed is not difficult to suggest. We and others have previously observed that the intact foetus responds to an asphyxial insult by increasing its blood pressure, maximally vasodilating its cerebral vasculature, and paralyzing its capability to autoregulate. ${ }^{2,3}$ Cerebral oxygen delivery is maintained because of the increase in rCBF. In the face of this compensation, any agent which produces foetal hypotension will correspondingly reduce foetal cerebral blood flow, cerebral oxygen delivery and potentiate the possibility of ischaemic cerebral damage. ${ }^{6}$

The reductions in rCBF observed with thiopentone (about 20 and 40 per cent with the two doses) correspond to reductions in foetal blood pressure of 15 and 22 per cent while the changes in cerebral blood flow seen with ketamine (about 7 and 33 per cent reduced) correspond to 7 and 10 per cent reductions in foetal BP (Figure 1).

At the higher dose of ketamine, foetal BP was fairly well maintained but $\mathrm{rCBF}$ values fell markedly, suggesting some other mechanisms for the reduction in cerebral blood flow. Development of foetal cerebral oedema or an elevation of foetal cerebral venous pressure could also produce a fall in $\mathrm{rCBF}$ as could active vasoconstriction in cerebral arterioles. The present study does not indicate which of those factors might be operative. 


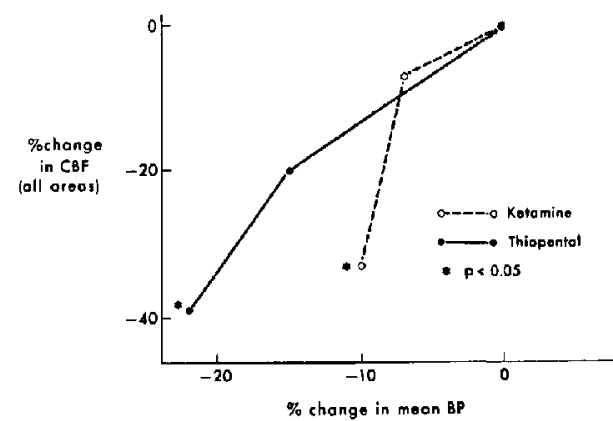

Figure 1 Relationship between total cerebral blood flow and mean arterial blood pressure in the acidotic sheep foetus following thiopental and ketamine.

Although one must always be careful in extrapolating animal data to human situations, our data suggest that, in the presence of foetal asphyxia, low dose ketamine may be preferable to thiopentone as an induction drug.

\section{REFERENCES}

1. MYERS, R.E. The patterns of perinatal brain damage and their conditions of occurrence. Am. J. Obstet. Gynecol. 112: 246 (1972).

2. Johnson, G.N., Palahniuk, R.J., Tweed W.A., Jones, M.V. \& WADE, J.G. Regional cerebral blood flow changes during severe fetal asphyxia produced by slow partial umbilical cord compression. Am. J. Obstet. Gynecol. 135: 48 (1979).
3. Lou, H.C., Lassen, N.A. \& Fris-Hansen, B. Impaired autoregulation of cerebral blood flow in the distressed newborn infant. J. Ped. 94: 118 (1979).

4. PAPE, K.E. \& Wigglesworth, J.S. Haemorthage, ischaemia and the perinatal brain. Philadelphia: Lippincott (1979).

5. SHNIDER, S.M. \& LEvinSON, G. Anesthesia for Obstetrics. Baltimore: Williams and Wilkins (1979).

6. Palahniuk, R.J., Doig, G.A., Johnson, G.N. \& PASH, M.P. Matemal halothane anesthesia reduces cerebral blood flow in the acidotic sheep fetus. Anesth. Analg. 59: 35 (1980).

7. LOU, H.C., LASSEN, N.A., TwEed, W.A., Johnson, G.N., Jones, M.V. \& Palahniuk, R.J. Pressure passive cerebral blood flow and breakdown of the blood-bain barrier in experimental foetal asphyxia. Acta. Paed. Scand. 68: 57 (1979).

8. Hellegers, A.E. \& Schrueffers, J.J.A. Nomograms and empirical equations relating oxygen tension, percent saturation and $\mathrm{pH}$ in maternal and fetal blood. Am. J. Obstet. Gynecol. 81: 377 (1961).

9. HALES, J.R.S. Radioactive microsphere techniques for studies of the circulation. Clin. Exp. Pharmacol. Physiol. Suppl. 1: 31 (1974).

10. Peltz, B. \& Sinclair, D.M. Induction agents for caesarean section. A comparison of thiopental and ketamine. Anaesthesia 28: 37 (1973).

11. Molr, D.D. Obstetric anaesthesia and analgesia. London: Balliere Tindall (1976).

12. Houlton, P.C., Downing, J.W., Buley, R.J.R. \& BRock-UTNE, J.G. Anesthetic induction for Cesarean section with thiopentone, methohexitone and ketamine. S. Afr. Med. J. 54: 818 (1978).

\section{RÉSUME}

On sait que l'asphyxie et l'acidose provoquent chez le foetus une augmentation du débit sanguin cérébral avec perte du mécanisme d'auto-régulation de cette circulation. Le but du présent travail était d'étudier, dans un contexte d'acidose foetale, les répercussions circulatoires cérébrales de l'administration de deux agents d'induction d'usage courant en anesthésic obstétricale, à savoir la kétamine et le thiopentone. On produisait une acidose chez le foetus de brebis préparées à cette fin. Des doses de kétamine $4 \mathrm{mg} \cdot \mathrm{kg}^{-1}$, de même que des doses de thiopentone $10 \mathrm{mg} \cdot \mathrm{kg}^{-1}$ produisaient dans ces conditions une diminution marquée du débit sanguin cérébral et du transport d'oxygène chez le foetus. La pression artérielle et le débit sanguin cérébral du foetus acidotique se maintenaient mieux lorsque de petites doses $\left(2 \mathrm{mg} \cdot \mathrm{kg}^{-1}\right)$ de kétamine étaient utilisées que lorsque l'on utilisait des doses inférieures $\left(6 \mathrm{mg} \cdot \mathrm{kg}^{-1}\right)$ de thiopentone. 